\title{
THE DEVELOPMENT OF RACIALLY DEFINED PUNISHMENT IN COLONIAL NATAL: THE EARLY HISTORY OF DURBAN'S POINT PRISON
}

\author{
Paul Swanepoel ${ }^{*}$ \\ Stephen Peté ${ }^{\star \star}$
}

\section{ABSTRACT}

This article traces the early history of the Point Convict Station situated near the entrance to Durban's harbour. Contained in the history of this building are a number of themes that are unique to the penal history of KwaZulu-Natal and, more widely, southern Africa. With its origins dating back to the turn of the twentieth century, this particular building symbolises the expression of a penal ideology, which we call "racially differentiated punishment". The building represents a particular regime of punishment that was reserved for non-European prisoners in particular. It is argued that, within the context of colonial Natal, a number of central themes distinguished the punishment of non-European prisoners from that of European prisoners at ideological level. White colonial authorities regarded labour as an extremely important element in the punishment of black offenders in particular. Further, there was a clear policy to push for complete racial segregation in the penal system of the colony of Natal around the turn of the twentieth century. In relation to this theme,

* Lecturer, School of Law, University of KwaZulu-Natal, Durban.

** Associate Professor, School of Law, University of KwaZulu-Natal, Durban. 
we explore the development of a penal ideology based explicitly on the separation of different racial groups - the significance of this lies in the fact that these policies were implemented almost half a century before the advent of apartheid in South Africa.

Keywords: Colonial Natal; Durban harbour; penal history; racially differentiated punishment; segregation

\section{Introduction}

This contribution is concerned with the early history of a relatively small and somewhat unremarkable building in the coastal city of Durban on the east coast of South Africa. Situated in the Point area near the entrance to Durban's harbour, the building falls within what is termed the Point Waterfront Development Area. Today, the building consists of a number of upmarket apartments, surrounded by a series of picturesque canals and is within easy walking distance of Durban's beaches, as well as major tourist attractions, such as Ushaka Marine World. Below the surface of the building's present genteel facade and surroundings, however, lies a somewhat darker, but fascinating, history. This building, today known as The Point Bastille, used to be Durban's Point Prison, and before that, it was known as the Point Convict Station. In the past, the building was occupied by - often dangerous - convicted offenders, rather than by well-to-do members of the bourgeoisie.

The building is, however, interesting for more than the mere fact that it used to be a prison. For tied up in the history of this particular building are many themes that are unique to the peculiar penal history of southern Africa in general and of KwaZulu-Natal in particular. With its origins dating back to the turn of the twentieth century, the building symbolises the articulation of a penal ideology which - for want of a better descriptive term - we call "racially differentiated punishment". To be somewhat more precise, the building represents a particular regime of punishment reserved for non-European prisoners in particular. It is contended in this contribution that, within the context of colonial Natal, a number of central themes or characteristics distinguished the punishment of non-European prisoners from that of European prisoners at ideological level. Among these distinguishing themes or characteristics two of the most important were the following: first, labour was regarded by the white colonial authorities as an extremely important element in the punishment of black offenders in particular. Convict labour was not only useful as a practical means of alleviating chronic shortages of so-called free labour in the colony. For the white colonists, convict labour performed by black prisoners was ideologically important, since a crucial pillar upholding and advancing the colonial project was the successful coercion of the indigenous black population into the habit of performing regular hard labour in service of their white colonial masters. The fact that - as is discussed in detail below - Durban's Point Prison was first conceived as 
a "Convict Establishment" to provide labour - in particular black labour - for the Harbour Works, is ideologically significant. This contribution explores a range of issues surrounding the theme of black prison labour.

Secondly, the punishment of black offenders in colonial Natal was inextricably bound up with resistance on the part of the indigenous population to oppressive colonial laws designed to enforce white colonial control. The prisons of the colony were not only expected to deal with criminals in the normal sense of the term, but also with offenders against social control legislation. The essentially political nature of many of the offences that landed a large number of the indigenous population in prison meant that "normal" penal theories did not give clear-cut answers as to how these prisoners should be treated. The early origins of the Convict Station at Durban's Point are intimately bound up with the crisis caused by the prosecution of large numbers of so-called rebels following the 1906 Bambatha Rebellion.

Both the above themes are explored in the context of the early history of Durban's Point Prison. It is the contention of this contribution that the establishment of the Convict Station at the Point was an important early stepping stone in the development of a system of "racially differentiated punishment". The fact that a penal ideology based on race was being developed at the turn of the twentieth century, which called for the complete and clinical separation of European prisoners from all non-European prisoners, is clearly significant, if for no other reason than that this took place almost half a century before the inception of the notorious apartheid system in South Africa. If the buildings which make up today's Point Bastille could talk, it is contended that they would reluctantly acknowledge their place within South Africa's cruel history of racial segregation and suffering.

\section{The social, political and economic context in Natal at the turn of the century}

Durban's Point Prison was established shortly after the start of the twentieth century. It is important, therefore, to understand the social, political and economic context within which the establishment of the prison took place. In particular, it is important to appreciate the manner in which the social, political and economic conditions of the time impacted upon the conceptions of race held by most members of the white colonial ruling class.

Towards the end of the nineteenth century, Natal's settlers became increasingly more independent of Britain. The colony attained responsible government in 1893 and this was accompanied by accelerated racial division. ${ }^{1}$ In particular, more legal obstacles for blacks were put in place in order to increase their social distance from white settlers. ${ }^{2}$ Economically, the discovery of gold on the Witwatersrand meant 
that the future of Natal became dependent on the economy of southern Africa as a whole. At the same time, the economy became increasingly racially skewed with the consolidation of settler agriculture. ${ }^{3}$

The years between the discovery of gold and the outbreak of World War I were characterised by increasing economic development in Natal. In particular, the desire to capture the trade of the Transvaal for Durban encouraged the modernisation of the harbour and the extension of the railway line to the Reef in 1895. As the railway line reached northern Natal, it became economically feasible to export coal. ${ }^{4}$ Before the 1890 s, commercial farming had been restricted to the coastal sugar plantations and market gardens near Durban and Pietermaritzburg. During this decade, there was a transformation of settler agriculture in the midlands and coastal districts. ${ }^{5}$ Crucially, the development of the goldfields also resulted in increased white immigration to southern Africa, including Natal, and by 1893, the white population had risen to 44 $000 .{ }^{6}$

Urban development stimulated the emergence of a white capitalist agricultural class. Agricultural organisations and farming members of the legislature argued the case for their protection and state support. With time, it became apparent that it was state intervention rather than market forces that gave them economic security. ${ }^{7}$ Over time, a sugar and coal alliance emerged as the principal economic unit in the colony. This period also saw the emergence of a white artisan class as a force in colonial politics. ${ }^{8}$

The growing self-confidence of the settlers shaped a separate ethnic consciousness. Politically, this meant greater settler control of the colonial administration. The defeat of the Zulu kingdom in 1887 put to rest fears of invasion, and between 1888 and 1893, Britain and the Natal legislature negotiated a new constitution. Important safeguards for black interests were included, but were allowed to lapse in practice. ${ }^{9}$ Responsible government in 1893 meant a transfer of power to the settler community. Even though urban voters were in the majority, the delimitation of constituencies ensured a majority of farmers' representatives. As a consequence, their demands dominated government policy. ${ }^{10}$

After 1893, there was a deterioration of race relations. White fear combined with racist attitudes towards blacks. ${ }^{11}$ These attitudes spread to the law, where many magistrates and judges were racially biased. During this period, Natal was influenced

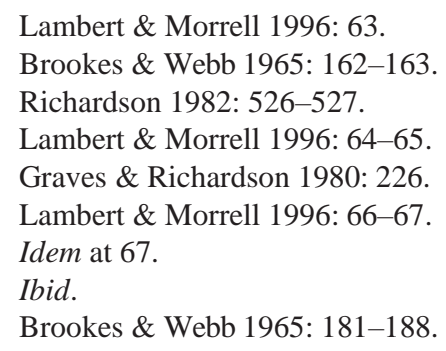


by the development of a segregationist ideology in the southern states of the United States of America. A dominant white consciousness developed, influenced by Social Darwinism. Part of this was the development of a theory of black inferiority. As a result, they were regarded as being incapable of assimilation. By 1897, the Indian population outnumbered the white population. As it gradually became a political and economic threat to certain settlers, the ethnic superiority of the latter was emphasised and the concomitant stereotype of the so-called dishonest Indian trader developed. ${ }^{12}$

The transfer of power to men with little sympathy for the aspirations of the black population contributed to the widening of the racial gulf. ${ }^{13}$ Between 1893 and 1910, forty-eight laws affecting Africans were passed. The Masters and Servants Law was tightened in 1896. In addition, the police force was expanded in 1894. In general, the sentences imposed on blacks by magistrates were harsher than they had been before responsible government. Courts frequently imposed the death penalty and bowed to settler demands for increased flogging. ${ }^{14}$

All of this explains why there was a push for a "formally racially divided" penal system - a move away from informal separation, which was always in place, to a formal separation. The main economic and political developments in Natal towards the end of the nineteenth and beginning of the twentieth centuries demonstrate why the colonists were so determined to create a racially exclusive prison for Europeans at this time.

\section{Early history of convict labour near the Point -1850 to 1901}

The earliest reference to the idea of establishing a Convict Station at Durban's Point, dates back to the early days of the colony, when John Milne, Durban's first harbour engineer, accepted a tender for the construction of an "iron convict house" to accommodate a small work gang in 1850 . As was to happen over many years to follow, however, these plans did not materialise.

From the 1860s onwards, convict labour was used on the Durban harbour works. It is important to note that there was a perennial shortage of labour in the colony. The constant complaints of white farmers about the shortage of labour were echoed by government officials in Durban, where there was a continuous need for labour to carry out public works. These public works included ongoing and crucial work on the construction of Durban's harbour. The use of convict labour for this purpose was frequently the only option available to government at a time when free labour was in short supply. ${ }^{15}$

12 Lambert \& Morrell 1996: 68.

13 Lambert 1995: 65.

14 Lambert \& Morrell 1996: 69-70.

15 Peté 1984: 18. 


\section{PAUL SWANEPOEL AND STEPHEN PETÉ}

Clearly, imprisonment in Natal was deeply affected by the prevailing economic and political situation in the colony. In general, the major shortage of free black labour influenced penal labour policy. In particular, gang labour on public works particularly the Durban harbour works - became an important form of penal labour. ${ }^{16}$ In 1868, the assistant resident magistrate of Durban stated that the facilities at Durban Gaol were inadequate to allow strictly penal labour to be carried out within the walls of the prison, stating that:

The change of air daily to the quarries and Harbour Works has the effect of keeping the prisoners in health and I question whether any greater punishment can be inflicted on Kafirs than having to work in chains regularly at the Harbour Works where they are continually exposed to salt water ... To white prisoners the exposure of having to appear in public amongst the Convict Gang is a greater punishment than any labour inside the walls of the Gaol could be. ${ }^{17}$

In speaking about "labour inside the walls of the Gaol", the assistant resident magistrate was referring to what was termed "strictly penal labour", whichinvolved economically useless labour - that is labour designed purely to punish and to reform the prisoner. It was performed inside the prison walls and usually involved walking on a treadmill, grinding a crank or performing "shot drill" with iron balls. Policy required the first three months of any sentence that included "hard labour" to consist of such "strictly penal labour". In practice, however, this policy was not applied in a sustained manner in the colony. To the prison authorities "on the ground", strictly penal labour was a waste of a precious resource - labour power and, in particular, black labour power - which was sorely needed on the public works of the colony. Clearly, the assistant resident magistrate wanted to assure the colonial authorities that "strictly penal labour" in the context of colonial Natal need not be performed inside a prison at some economically useless task. Such tasks included grinding a crank or walking endlessly on a treadmill that was put there purely for the purpose of punishment. ${ }^{18}$

In 1872, the Durban Gaol Board recommended that hard labour of the first class in Durban should comprise labour at the harbour works, at the Umgeni quarry and for public works. ${ }^{19}$ Generally, prisoners housed in the Durban Gaol did not experience a period of strictly penal labour, but were employed on the harbour works or other sites of public labour. Indeed, convict labour on the public works came to be regarded as crucial by the Natal penal authorities..$^{20}$

16 Idem at 23

17 Pietermaritzburg Archives Repository (hereafter NAB) CSO (Colonial Secretary's Office, Natal) 314/2265: Report of Assistant Resident Magistrate of Durban, 8 Oct 1868.

18 Peté 2006: 100-112 and Peté 2007: 111-125.

19 NAB CSO 405/307: Meeting of Durban Gaol Board, 6 Feb 1872.

20 Peté 1984: 49. 
Overcrowding was a common problem in Natal's prisons and the construction of a prison at the Point was suggested by the District Surgeon, Dr Gordon, in 1883. He supported the "construction of a separate establishment in the neighbourhood of the Point ... to be called the 'Convict Establishment' in which all long sentenced prisoners be kept and where Government work is always carried on [i.e. harbour works]". ${ }^{21}$

According to Dr Gordon, the treadmill, crank and shot drill were undesirable and had fallen out of favour with prison authorities in England. Instead, English convicts were employed on large public works. The Harbour Board in Durban, however, believed that a separate convict station near the harbour was not feasible. In 1883, the Board estimated that fewer than 100 convicts working at the harbour would be required and suggested that, instead of at the Point, the proposed convict station be situated near a large quarry. This, it was thought, would provide sufficient work for the inmates. ${ }^{22}$ It is not clear, however, if such a convict station was ever established.

The idea of establishing a convict station near the harbour works at Durban's Point again came to the fore in 1887. In that year, Edward Innes, the harbour engineer, observed that a prison at the Point would be advantageous as the Durban Gaol was nearly two miles away. The Breakwater Gaol in Cape Town was cited as an example of a gaol built to house convicts close to their place of work. The following year, Cathcart William Methven, Innes's successor as harbour engineer, identified a site on reclaimed land near a location known as the Back Beach. Once again, the idea was stillborn and no construction was actually carried out. ${ }^{23}$

As for the nature of the labour performed by convicts in connection with the Durban harbour works, much of it involved working with stone. In order to fulfil the requirements of prison sentences which included "hard labour", convicts in the main worked with stone that was produced at a quarry overlooking the Umgeni river. Blocks of stone were broken into smaller pieces and then transported by rail to the Point. Upon arrival, gangs of convicts unloaded the blocks and moved them to the North Pier, the breakwater or to the large concrete block yards. Convicts not employed at the quarry or at the Point were still involved with stone breaking, but this was carried out within the Durban Gaol. ${ }^{24}$ The hardest form of labour was considered to be working with stone. Accordingly, much of the work performed by convicts at the harbour concerned breaking, crushing or carting stone. ${ }^{25}$ When the large block yard near the beaches was extended in 1906, convicts were used to remove the sand hills.

21 NAB CSO 897/858: District Surgeon, Pietermaritzburg, to Resident Magistrate, Pietermaritzburg, 14 Apr 1883.

22 NAB CSO 879/858: Report of Resident Engineer, 6 Jul 1883.

23 Kearney 2013: 1239.

24 Idem at 1233.

25 Idem at 1221. 
From 1905, convicts were also involved in levelling the ground and preparing the building sites for new quays and warehouses on the Maydon and Congella wharfs. ${ }^{26}$

Together with road construction, the harbour works were generally considered an appropriate place for prisoners sentenced to imprisonment with hard labour. Successive harbour engineers called for increased convict labour, since convict labour supposedly cost half the amount of that paid for contract workers. Few officials spoke out against convict labour, with one rare example being the assistant commissioner of police and inspector of prisons, Mardell, who commented in 1909 that "instead of being a valuable asset, convict labour is in reality a burden on the Colony". ${ }^{27}$

A final strand in the early history of convict labour at Durban's Point worthy of discussion, is linked to the Second Anglo-Boer War, which raged between October 1899 and May 1902. During the war, large numbers of Africans had collaborated with the Boers. ${ }^{28}$ Soon after the turn of the century, some were incarcerated on the Bluff, the peninsula that lies just across the mouth of the harbour from the Point. During the course of the war, procedures were developed to deal with prisoners taken by the British army. Citizens of the Transvaal and Orange Free State were treated as POWs. Persons who held allegiance to the colony of Natal and who had collaborated with the Boers were charged with high treason. Ultimately 409 men were convicted, 14 of whom were Africans. The longest sentence handed down to an African was three years with hard labour. However, Africans in Natal could also be charged under martial law for collaborating with the Boers ${ }^{29}$ In addition, a large number of Africans were held in prisons across Natal on suspicion of collaborating with the Boers, but who had not yet been tried..$^{30}$

In deciding what to do with these men, Major General James Wolfe-Murray of the British army approached the Natal colonial government about using the men as public labourers, since the war had resulted in a major labour shortage at the Durban harbour. It was agreed that the harbour works in Durban would be the most practical site to put the men to work. However, a plan to accommodate these men within the Durban Gaol did not materialise. Instead, the men were accommodated in a separate building on the Bluff, which, it was believed, would make escape difficult. ${ }^{31}$ Clearly, the authorities did not wish to treat these men as criminal prisoners in the strict sense of the word, but at the same time wanted them to be kept under control and under surveillance in order to prevent them from deserting. In the end, guards were provided by the Harbour Works Native Police. It was agreed that the men would be

26 Idem at 1235.

27 See Nongqai II (12), 377 as cited in idem at 1221. Nongqai was the Natal Police journal at the time.

28 Warwick 1980: 198-199.

29 Wassermann 2011: 28.

30 Idem at 29.

31 Wassermann \& Wohlberg 2002: 125. 
paid thirty shillings a month minus deductions for food and accommodation. After deductions, the men only received half this amount. Administratively, the men were treated as POWs. Legally, however, they did not have this status. ${ }^{32}$ The Minister of Lands and Works, AH Hime, recognised the special status of these men when, in 1900, he stated in an instruction to the harbour engineer as follows:

All that is necessary, I think, is to keep a general watch over these men by day so as to prevent their trying to desert. They must not be treated as prisoners and, therefore, I think that they had better not be put in gaol at all. If special guards have to be employed, they will have to be paid for by the Military Authorities. ${ }^{33}$

This lack of status allowed the authorities to exploit the men as forced labour. The labour performed by the men was equivalent to the most severe punishment reserved for criminal convicts, namely work on the harbour breakwater. By December 1901, 215 men were imprisoned and employed on the Bluff. Crucially, the urgent needs of the government at this time for labour were linked directly to the search for a "native policy" that would satisfy this need for workers. ${ }^{34}$

By 1901, the total number of convicts working at the harbour, including the "suspects" imprisoned as a result of the war, had reached over 400. This was the highest number of labourers employed at the harbour works up to that time. ${ }^{35}$ It is important to note that, during that period, the prisoners accused of collaboration with the Boers had not been charged with high treason in the civilian courts, nor had they been charged under martial law. They were merely arrested under suspicion of collaborating with the Boers and then used for purposes of forced labour. This without any proper trial in a court of law.

The employment of these men as forced labourers is a serious indictment of the attitudes of the military authorities and the colonial government at the time. If they were legitimately suspected of having committed treason, they should have been subjected to a court martial, or else properly charged and tried in a civilian court. However, they were neither properly tried and convicted, nor were they set free, but simply designated as "suspects" and made to perform hard labour at the harbour works. Significantly, certain district magistrates became concerned about the welfare of these men and, from June 1901 onwards, were involved in a process of securing their release.$^{36}$ What emerges clearly from this particular strand in the early history of convict labour at Durban's Point, is the attitude of the white colonial authorities in relation to "Native" prisoners. Uppermost in the minds of these authorities was

32 Wassermann 2011: 27-39.

33 NHD II/1/25, Natal Harbour Department, Engineer's Correspondence, 10-18 Apr 1900, cited in Kearney 2013: 1227.

34 Wassermann 2011: 27-39.

35 Kearney 2013: 1231.

36 Ibid. 
the potential labour these prisoners could perform in service of the white colonial project. Of much less importance was the precise legal status of these prisoners. Furthermore, there was no notion that the work performed by these men might be necessary to reform any criminal tendencies they might harbour. As in the case of many non-European prisoners confined within the gaols of colonial Natal, everyone knew that these men were not criminal in any real sense of the word, but simply members of the indigenous population who had dared - in some way or other - to defy the white colonial order.

\section{The 1904 campaign for prison reform in the Natal Witness and the appointment of a commission of inquiry}

In May 1904, the editor of the Natal Witness - F Horrace Rose - launched a campaign in his newspaper aimed at bringing about prison reform in the colony of Natal. The main focus of the campaign was on what the white colonists thought to be the many deleterious effects of confining white and black prisoners in the same gaols. Although European prisoners in colonial Natal had always been confined in cells separate from those in which prisoners of other races were confined, Rose's campaign called for complete separation, with the establishment of a new type of prison designed specifically for the confinement of European prisoners. This prison was to be entirely separate from the other prisons of the colony, which would then cater exclusively for non-European prisoners. The penal ideology underpinning the punishment to be meted out in the proposed new and exclusive European prison, was to be completely distinctive from that which informed the punishment of nonEuropean prisoners.

As Rose's campaign began to gain strength within the white colonial community, questions were asked in the Natal parliament about what the government intended to do in relation to prison reform. The Minister of Justice promised to look into the matter, which resulted in information being obtained from England, Australia and the United States. On 29 December 1904, the Natal Witness reported that proposals had been drawn up that were to be presented to parliament. The newspaper stated as follows: "One of the most important reforms which will be instituted is the complete segregation of European prisoners, thus doing away with the scandal of herding black and white prisoners in the same gaols." ${ }^{37}$

It was proposed that the Central Gaol in Durban, which stood on a valuable site in the centre of the city, be sold. The proceeds were to be used to build a new prison near Pietermaritzburg for Europeans - which was to be focussed on industrial training - as well as a new prison at the Point for non-Europeans. The new prison 
at the Point was to be focussed on the provision of labour for government projects and was to be situated as near as possible to the harbour works. This proposal clearly indicates the different penal ideologies underpinning the punishment of white and black prisoners. The proposed new "industrial prison" for Europeans would be geared to the reform of its inmates by training and education. In contrast, the new prison at the Point would be focussed on harsh punishment by means of hard manual labour. Not only would this new prison for non-Europeans teach the lesson that the indigenous inhabitants of the colony should reconcile themselves to performing menial labour in service of their white colonial masters, but it would be practically useful in providing a convenient and secure source of forced labour for the Durban harbour works. All talk of 'reform' and the 'treatment of the criminal disease' was not applicable to black prisoners. The control of an unwilling and repressed black labour force was dependent upon a system of harsh punishment, which would deter opposition to white colonial authority and bolster white colonial power. There were fears among certain white colonists, particularly those who employed black labour, that all the talk of prison reform at this time would lead to excessive leniency being shown towards black prisoners. Many white employers felt that the penal system was already too lenient towards black prisoners. This matter was brought up in Parliament on 28 June 1904, with one of the members stating as follows:

\begin{abstract}
We know very well, all of us who are employers of Indian labour, what the Indians opinion of the gaols of Natal is. They think they are the finest places in the world to go to, that they are far less hard worked there than they are on the estates of their employers, and the same remark applies to Natives ... Although I am in favour of doing as much as possible to improve the condition of the white prisoners ... I certainly, Sir, am not in favour of relaxing in any way the punishment of the Indians and the Natives. ${ }^{38}$
\end{abstract}

Clearly, the fact that the government proposed to build completely separate prisons for black and white prisoners - to be run along completely different lines - indicates that the above argument was indeed taken seriously. The proposals put forward by the government did not, however, end the agitation for prison reform. It was felt by many that a full-scale parliamentary commission was required to investigate a matter so complex and important. On 10 February 1905, several prominent white colonists petitioned the government to appoint such a commission. ${ }^{39}$ Just over two weeks later, on 28 February 1905, the Natal Witness announced that a Prison Reform Commission was to be appointed..$^{40}$ The commission was officially appointed on 16 September 1905 and completed its final report on 28 May 1906; ${ }^{41}$ it cast a wide net during its

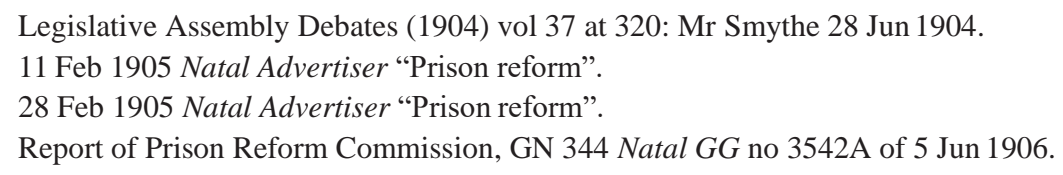


investigations, taking evidence from sixty-two witnesses on twenty-three separate occasions and visiting the central gaols (Durban, Pietermaritzburg and Eshowe), as well as certain of the more accessible district gaols of the colony. ${ }^{42}$ Copious documentary evidence was solicited by means of a wide-ranging questionnaire, which was sent to a large number of officials throughout the colony who were in any way involved in the administration of the penal system..$^{43}$ In addition - apart from the district surgeons of Pietermaritzburg and Durban who gave verbal evidence before the Commission - a separate list of questions was sent to all district surgeons who were in medical charge of the gaols of the colony. ${ }^{44}$ Finally, advertisements were published, inviting any members of the public who wished to do so, to give evidence before the Commission. ${ }^{45}$

\section{The report of the Prison Reform Commission of 1905-1906: Ablueprint for racially differentiated punishment}

The report of the Prison Reform Commission provides fascinating insights into the political and economic challenges facing the colony of Natal at the turn of the previous century, as well as the manner in which the racist ideology of the white colonial ruling class shaped official responses to broad issues of prison reform. The scope of the enquiry was framed in very broad terms, with the Commission being instructed "to enquire into, and report upon the whole question of Prison Reform and Penology in Natal". ${ }^{46}$ At a practical level, th main problem facing the penal system at the time was constant and serious overcrowding. ${ }^{47}$ The issue of race immediately entered the picture, since the problem of overcrowding was exacerbated by the fact that - as far as possible - European prisoners had to be kept apart from prisoners of other races - in other words, prisoners could not be spread evenly among available cells. ${ }^{48} \mathrm{As}$ will be made clear later in this section, there had always been a (somewhat informal)

$42 \quad$ Idem pars 3 and 8.

43 Idem par 4.

44 Idem par 5.

45 Idem par 3.

46 Idem par 1.

47 In relation to overcrowding, the report stated, inter alia, as follows: "In the ... [Durban] Gaol the pressure upon cell space has at times been so great that numbers of prisoners, (as many as eighty on one occasion), have had to occupy the corridors. Considering merely the factors of amount of floor space, cubic capacity, and number of inmates, the cry which has been going up for years of overcrowded gaols is, having regard to existing conditions, undoubtedly well founded ... [I]t is sufficient to say that the gaols as a whole are inconveniently, and at times dangerously, overcrowded." See idem par 22.

48 Referring to the Central Gaols, the Commission pointed out that the separate confinement of European prisons had a deleterious effect on the overcrowding of prisoners of other races: " $[I] \mathrm{n}$ cells of similar dimensions to those in which one European was confined were found three, and sometimes five, Natives or Indians." See idem par 22. 
separation of prisoners of different races in the gaols of colonial Natal, but the turn of the century marked an inflection point at which this separation was to become more formalised and carefully articulated within official policy. The recommendations of the Prison Reform Commission, it is argued, represent an important early expression of official policies of racial segregation and separation within the penal sphere. The fact that these policies were being articulated at the turn of the twentieth century, half a century before the adoption of the notorious apartheid system, is worthy of note.

The basic logic underpinning the various recommendations made by the Commission was that many of the problems being experienced within the penal system of colonial Natal at the time - with overcrowding being chief amongst these problems - could be solved if the prison population could be separated into a number of carefully defined categories, each of which would then be dealt with accordingly. Not surprisingly, the primary division would be along lines of race, with European inmates being separated, removed from the system, and dealt with on a completely different basis to all other prisoners. This step alone would take a certain amount of strain off the overcrowded penal system, but it was possible to reduce the strain even further by removing a substantial group of so-called native prisoners from the overcrowded prisons. This was the large group of native offenders in Natal's gaols who had been imprisoned, not because they were real criminals, but because they had fallen foul of some or other article of social control legislation - that is, colonial legislation designed to keep Natal's indigenous population under firm white colonial control. Once this large group of petty political offenders had been removed from the system (since they did not belong in a real prison in any event), along with the European offenders, the pressure on Natal's penal system would be greatly relieved.

These proposals require closer investigation, since the manner in which they were framed by the Commission provides fascinating insights into white colonial ruling class ideology at the time. Together, they amount to what we have referred

to as a "blueprint for racially differentiated punishment". The subsections that follow examine first, the proposals of the Commission in response to the problem of tightening up the manner in which various racial groups were defined, in order to ensure that only "pure blooded Europeans" were singled out for preferential treatment. Secondly, the proposals related to the preferential treatment to be provided to European prisoners are studied. Thirdly, the contribution takes a look at the proposals related to the separation and treatment of so-called native petty offenders, in particular the obsession of the white colonists with the control and exploitation of native labour.

\section{The problem of defining and separating different races}

As alluded to above, a primary point of departure of the Prison Reform Commission was that the penal system of colonial Natal was plagued by excessive overcrowding 
and that it exercised a corrupting influence on all those who came into contact with it. It was pointed out that the system made no attempt to differentiate between various types of criminals. The gaols were "used alike for the detention of the convicted and un-convicted of all races and ages, of both sexes, and of all degrees of criminality, from the mere offender against an artificial prohibition to the most villainous transgressor of human and divine law" ${ }^{49}$ This did not mean, of course, that there was no separation within the prisons. No matter how small the gaol, female prisoners were always separated from male prisoners, although it would seem that female prisoners were few and far between. More importantly, European prisoners were always separated from prisoners of other races..$^{50}$

The distinction between European and non-European prisoners was the one that really mattered to the white colonists in general and to the white prison authorities in particular. The trouble - according to many of the white colonial officials who administered Natal's penal system - was that the existing definition of "European", as it applied in the prisons of colonial Natal, was not exclusive enough. The Commission pointed out that the definition of "European" in terms of the prison rules was tied up with prison diet: "Broadly, the rules recognise, for dietary purposes, three races, viz.: Europeans, Indians, and Natives. Included among the first are Eurasians, natives of St. Helena and the Cape (excluding Kafirs), American Negroes, French Creoles, and West Indians."

The white colonial prison authorities were strongly opposed to this extended definition of "European" and argued strongly for a more exclusive definition. The Commission agreed with the need for more precise racial distinctions to be made within the penal system of the colony, particularly when it came to who was and who was not classified as a "European":

The above divergent races, now classified alike as Europeans, may be found confined in the same cell, simply because they are supplied with the same kind and quantity of food. These inexact distinctions were universally condemned; and this notice of the matter, in conjunction with other points more less patent, should lead to an immediate revision of the rules. As regards racial distinctions, a re-classification was strongly urged, excluding so- called "Coloured" people from the category of Europeans, and placing them in a class by themselves. ${ }^{52}$

49 Idem par 25.

50 When describing the overall state of the colony's prisons, the Commission made it clear that, despite constant problems with overcrowding, there was strict separation between European prisoners and prisoners of "other races": "Europeans by themselves or in single cells so far as space permits, other races three or more in a cell, according to certain ideas regarding health and morality." See idem par 22.

51 Idem par 26.

52 Ibid. 
Thus, the first step towards ensuring the separate treatment of European prisoners was to exclude all non-Europeans, hence the proposed addition of a catch-all racial category termed "Coloured" to the existing categories "European", "Indian" and "Native". ${ }^{53}$ It was thought that this would avoid anomalies in classification since, if a prisoner did not fall clearly under one of the three principal categories, he would automatically fall under the "Coloured" category. Only "pure blooded white men" would be entitled to treatment under the proposed industrial reformatory system. ${ }^{54}$

Clearly, the white colonial ruling class wished to prevent any mixing between Europeans and non-Europeans, thereby preserving a strict social distance between these two groups. The maintenance of white colonial authority and sovereignty demanded that whites - even in prison - be seen as belonging to the white master class and therefore completely separate from the indigenous population. ${ }^{55}$ Perceptions of white superiority and supremacy had to be jealously guarded, if firm ideological control over the indigenous population was to be maintained.

\section{Separate treatment for Europeans}

Having tightened up the definition of "European"” so as to allow only "pure blooded white men" to take advantage of this category, it would become possible to extract the European prisoners and to place them in their own special prison where they would get special treatment, as befitted representatives - albeit wayward ones - of the white colonial ruling class. As a matter of the "first order of importance", the Commission suggested "the erection, outside any of the towns, of a separate gaol for Europeans, at which industrial work and reformative methods could be carried on simultaneously". ${ }^{56}$ This formed an important piece of the puzzle in the overall picture of a system of racially differentiated punishment being proposed by the Commission.

The Commission also pointed out that "the main object of the institution [namely the proposed new prison for Europeans] would be reform". ${ }^{57}$ The Commission made it clear that the formal racial segregation of prisoners, which would be effected if

53 Ibid

54 NAB CSO 2847/Précis of Evidence at 1.

55 The attitude of the colonists towards the perceived dangers of racial inter-mixing - evenamongst prisoners - is well illustrated in the following extract from the précis of evidence presented to the Commission: "Several witnesses have commented on the exceeding difficulty of keeping the races apart when in the same building; and it would appear that even the white man, when in prison, tends to make friends with those other prisoners who he might be expected to look upon as belonging to the inferior race." See ibid.

56 Report of Prison Reform Commission, GN 344 Natal GG no 3542A of 5 Jun 1906 par 30

57 Idem par 30. In this same paragraph of its report, the Commission went on to state that: "An independent prison for Europeans, with its different sections for Adults and Juveniles, Inebriates and Vagrants, must be the foundation of any attempt by the State to protect Society through the reclamation of the fallen and the criminal." 
the new European prison was established, would simply be building on the de facto racial segregation that already existed in the prisons of the colony:

The erection of such a prison in itself involves no revolution of our gaol system; for the aim and policy of the present management is, as regards diet and so far as accommodation permits, to separate the White from the Black, allowing only that which is unavoidable, their association in the labour gangs and workshops. ${ }^{58}$

Thus, in terms of the Commission's proposals, the de facto racial segregation that had always existed in the prisons of the colony, was to be sharpened up, formalised and taken to its logical conclusion, that is, by establishing a completely separate prison for Europeans.

The complete racial segregation of the prisoners would also apply in the case of juvenile offenders. The Commission suggested that a "special and independent Reformatory for Juveniles" could eventually be established as a separate section of the proposed "General Reformatory" - that is, as part of the proposed prison exclusively for Europeans discussed above. ${ }^{59}$ Until such time as numbers justified a separate reformatory for European juvenile offenders, the Commission suggested that "Natal might follow the example of the Transvaal and Orange River Colony, in sending her [European] juvenile offenders to the Reformatory near Cape Town, where they are received at a charge of two shillings and sixpence per head per diem". ${ }^{60}$ The Commission was clearly concerned with keeping white juvenile offenders far away from the corrupting influences of the colony's prisons and stated as follows:

Many of these youths are not brought before the Courts at all, and such as may be are generally warned or birched and then discharged. Under a First Offenders' Act, operating in conjunction with a system of benevolent supervision by specially qualified 'probation officers', and with other forms of corrective treatment suited to the perversity of youth, under the supervision of the Education Department, elsewhere alluded to, it may be possible to defer for many years the establishment of a Reformatory for Juvenile Europeans ${ }^{61}$

Thus, when it came to the treatment of European juvenile offenders, it was all about "education", "training" and "reform". In preference to "penitentiary incarceration", the Commission stated that "it is desirable that other and less rigid disciplinary methods should have preference in the training of disorderly and neglected youths". ${ }^{62}$

58 Ibid.

59 Ibid.

60 Ibid.

61 Ibid.

62 Ibid. It was clear that these sentiments only applied in the case of European youths, with the following course of action being recommended by the Commission for so-called native youths: "As regards Native youths of lawless tendencies, the Judiciary should be granted a discretionary power, in dealing with First Offenders, to free towns from their presence by ordering them back to their kraals, as a substitute for police or probation surveillance." 
One reason advanced for restricting industrial training to white prisoners was the resistance that could be expected from white labour if black prisoners were trained:

The needs of the Public Works and the Harbour Departments afford ample outlet for all Coloured Convict Labour; and the industrial training of Native and Coloured Convicts would be probably resented as likely to cause unfair competition with white skilled labour. ${ }^{63}$

The above reasons were only mentioned in the evidence presented to the Commission, however, and did not appear in the final report. Instead, the report justified restricting reformative methods to white prisoners in purely racist terms:

Pride of race alone ought to rouse us from our indifference and lethargy ... Several reasons may be suggested for limiting the proposed innovation to Europeans; of a higher average intelligence, and possessing a higher moral basis, with a better knowledge of the claims of society, and of the advantages of being reconciled thereto, they offer a more promising field for reform than would be presented by individuals of other races. ${ }^{64}$

It is worth emphasising that the establishment of a reformatory or industrial prison for Europeans was regarded as an absolute priority by the Commission, which stated that: "The opinion was universal, and in it your Commissioners most emphatically share, that one of the first measures of reform should be a separate prison for Whites." ${ }^{65}$ Although, as will be discussed in due course, this recommendation was never fully implemented at the time, its nature and scope are important for a proper understanding of penal ideology of the white ruling class in the colony during the early part of the twentieth century. The idea that punishment affected blacks and whites differently, and that the penal system should be divided along lines of race, was fundamental to the findings of the Commission. The treatment of the European prisoners in the proposed industrial prison was to be geared towards education and reform, which would enable that prisoner to re-enter white colonial society upon their release.

\section{Social control, labour and the treatment of "native" prisoners}

In the case of so-called native prisoners, the main concern of the Commission was the overcrowding of the prisons with black petty offenders against social control legislation. If at all possible, these offenders - who were not really criminals in the true sense of the word - had to be kept out of prison. At the same time, however, white colonial sovereignty and authority had to be protected against these rebellious natives. An ideal solution was to place these recalcitrant members of theindigenous

63 NAB CSO 2847/Précis of Evidence at 6.

64 Report of the Prison Reform Commission, GN 344 Natal GG no 3542A of 5 Jun 1906 par 67.

65 Idem par 69. 
population into labour camps, where they could be reconciled to performing menial hard labour in service of their white colonial masters. The remaining hardcore criminals within the native prison population would be left behind in the prisons now much less crowded - to be dealt with accordingly.

In order to properly understand the Commission's approach to the treatment of native prisoners, it should be noted that, from the time that they were first established, the prisons of the colony had always performed a dual role. On the one hand, they were instruments of social control - many of the inmates detained in these prisons were there because of resistance on the part of the indigenous population to white colonial control. On the other hand, they were instruments for the suppression of crime in the strict sense of the word. This dual role was apparent in the design - or lack thereof - of many of the gaols in the colony. In commenting on the manner in which many of the "country gaols" in the colony had been constructed, the Commission pointed out that "they were not erected in accordance with any general and approved scheme of gaol construction", but had "mostly grown by a process of accretion in irregular additions, varying in description, appearance, and stability according to individual fancy, the pressing needs of the locality, or the financial necessities of the time". ${ }^{66}$ As if to emphasise that the prisons of the colony were not designed simply to suppress crime and criminals, but to enforce colonial power in the face of a rebellious indigenous population, the Commission pointed out that many of the country gaols were designed to be "defensible positions":

Considerations of defence had to be studied in their erection and in enlargement; the Gaol, in conjunction with the Public Offices of the Division, forming the principal and possibly the only defensible position within most Magistracies; and for this reason also they were generally, and still are, at these places used as arsenals for the storage of arms and ammunition. ${ }^{67}$

The Commission made clear in its report that many black prisoners - who made up the vast majority of Natal's prison population - had ended up in prison because of what were - essentially - political offences against social control legislation:

The Natives are not only subject to their own special laws, of which there are many contraventions, but also to a number of artificial restraints and disabilities, chiefly when in towns, which go to swell the number of offences committed by them. ${ }^{68}$

Thus, the prison authorities clearly understood that the overcrowding in the prisons of the colony was largely the result of sending to prison black offenders against legislation, such as the Native Code, Pass Laws, as well as the Master and Servants

66 Idem par 13.

67 Ibid.

68 Idem par 67. 
Law, as they could "in no sense of the word ... be said to be criminals" ${ }^{69}$ In its final report, the Commission commented that it was not desirable to sentence petty offenders to short sentences of imprisonment, and noted that: "[m]any of such cases, perhaps the majority from the towns, do not indicate any particular moral depravity, arising from nothing worse than a breach of artificial restraints and prohibitions". ${ }^{70}$ The Commission proposed a number of ways in which such offenders could bekept out of the existing overcrowded prisons. These included banishing such offenders to their kraals; punishing by means of corporal punishment rather than by short sentences of imprisonment; and sentencing petty offenders to work on the roads or other public works.

It was in relation to the proposal that black petty offenders be sentenced to forced labour on the roads and other public works, that the Commission made one of the most consequential recommendations of its report. This was the recommendation that a number of "movable" or "portable" prisons be established. These movable prisons would be similar to road construction camps, but would be designed to ensure the safe custody of short-sentence black prisoners when they were not working on the roads. They would consist of "portable iron pent-houses, similar to those in use by the Railway for construction work" and would be surrounded by barbed wire entanglements. ${ }^{71}$ Prisoners would be employed for road construction and -repair during the day, and confined within this fortified camp at night. The prison would be moved as the work progressed. The Commission pointed out that the advantages

69 NAB CSO 2847/Précis of Evidence at 2. In par 44 of its report, the Commission stated as follows: "The system of advancing money to Natives, in order to secure their services, is said to be responsible for many cases of imprisonment under the Masters and (Black) Servants' Act. The contract, which was purely civil in its inception, becomes quasi-criminal in its developments, and lands the defaulting debtor in gaol as a defaulting servant." See Report of Prison Reform Commission, GN 344 Natal GG no 3542A of 5 Jun 1906 par 44. Examples of such laws include the Natal Native Code of 1891, the Identification of Native Servants Act 49 of 1901 and the Masters and (Black) Servants Act 40 of 1894.

70 Idem par 45. A good example of the "artificial restraints and prohibitions" that the black indigenous population were subject to in colonial Natal, were the many restrictions put in place by the Masters and (Black) Servants Act 40 of 1894. Contraventions of this piece of legislation were frequent, and in great part responsible for the overcrowding in the colony's gaols. In order to secure black labour, white employers or their labour agents would loan money to members of the indigenous population, on condition that the debt was repaid by means of labour service to the particular employer. The labourer would become tired of working for no wage, and would desert. This would render him liable to imprisonment under the Master and Servants Act. Thus, a contract which was "purely civil in its inception", became "quasi-criminal in its developments". See idem par 44. Another example of "artificial restraints and prohibitions" was the infraction by members of the indigenous population of the "Borough by-Laws". The Commission pointed out that in such cases a curious anomaly arose: "If the delinquent pays the fine, the Corporation benefits; if he does not, the Government has to bear the cost of his imprisonment, receiving a poor returned from his labour." See idem par 46. Clearly the criminal law was not being used merely to combat crime, but also as an instrument of civil oppression and control. Imprisonment as a response to essentially civil infractions was both unnecessary and expensive in the eyes of the Commission.

71 NAB CSO 2847/Précis of Evidence at 4. 
of establishing such movable prisons throughout the colony was that they "would in a short time repay their cost by obtaining better results in labour, and improved sanitary conditions in all the gaols [namely by reducing overcrowding in existing gaols]". ${ }^{72}$ To sum up, these prisons were to be a cost-effective way of dealing with the large number of non-European prisoners who were "not criminals in the proper sense of the word", but who had been caught up in the penal system because they had fallen foul of racist social-control legislation, or had more actively resisted colonial control. ${ }^{73}$ Petty offenders of this kind did not need to be reformed. Rather, they had to be taught a simple lesson, which was to obey white colonial authority and to perform hard labour in support of the colonial state. Clearly, education, reform and "scientific treatment" were not priorities when it came to the punishment of the large majority of black prisoners.

It is clear from the overall tone of the Commission's report, that a central concern of the white colonial authorities was the quality and quantity of the labour performed mainly by black prisoners. In the first stages of its report - in its overview of the overall state of the penal system of the colony - the Commission made special mention of "the manner of employing prisoners on Public Works in the country districts". ${ }^{74}$ After pointing out that such prisoners were generally employed doing work on the roads in small gangs under the control of "Native guards", the report makes the following telling comment:

The Native makes an excellent guard, but a poor ganger; and to expect men, lacking the directing and organising faculty, to manage a gang of labourers is the incipient and innate fault of the system, and is largely accountable for its indifferent results. To the employment of Native prisoners under the sole supervision of Native guards, as is generally the rule throughout the Colony, is to be attributed the common belief that a sentence to hard labour, at a District Prison, is a misnomer and almost a farce. Even when a European is in charge of the gang, the amount of road-work performed is much below possibilities. The more profitable use of prison labour is a point requiring special consideration. ${ }^{75}$

As pointed out above, the Commission regarded the establishment of movable or portable prisons - essentially forced labour camps for non-European prisoners - as a means of relieving the serious and persistent problem of overcrowding. Describing the establishment of such prisons as "one of the great desiderata in prison reform

72 Report of the Prison Reform Commission, GN 344 Natal GG no 3542A of 5 Jun 1906 par 29. It is interesting to note that, in the discussion of the industrial prison for Europeans, the principle of reformation and the sympathetic treatment of the white criminal was seen to override objections of excessive cost. On the other hand, the concept of movable prisons seems to have been inspired primarily by economic considerations - namely at reducing the costs of maintaining short-term black prisoners, while at the same time effectively utilising black prison labour.

73 The Bambatha Rebellion took place in 1906.

74 Report of Prison Reform Commission, GN 344 Natal GG no 3542A of 5 Jun 1906 par 16.

75 Ibid. 
in order to relieve the prevailing and ever-growing congestion of our gaols", the Commission set out the following reasons in support of its opinion:

Their construction and equipment would be comparatively inexpensive, and they would be the means of improving the sanitary conditions of the gaols, and at the same time securing a higher return from ordinary unskilled prison labour ... [I]n view of the urgent need for reducing the number of inmates in many of the country gaols, the establishment of this class of prison should have immediate attention. Those sent to them should be Natives and Indians under short sentences, including all those who are not criminals in the proper sense of the word, as well as those who are unable to pay their fines. ${ }^{76}$

It is not difficult to perceive - just beneath the surface of these words - the nagging obsession of Natal's white colonists with securing and effectively controlling the power of black labour. The above passage also makes it clear that all those involved in the Commission understood full well that - to a significant extent - the penal system of the colony operated as a method of social and political control, rather than as a mechanism for the suppression of crime and criminals. In other words, it was clearly understood by all that the prisons were being used as a political tool to secure the compliance with colonial authority and domination of a reluctant and rebellious indigenous population. Hence the telling phrase in the above quotation that "all those who are not criminals in the proper sense of the word" should be sent to the proposed movable or portable prisons, perhaps more accurately described forced labour camps for, essentially, political opponents of the colonial project. ${ }^{77}$

An important point emphasised by the Commission in relation to prison labour was that it should be economically valuable. The labour shortages that had plagued the white colonists over the years, as well as the long and difficult struggle of the white colonial state to prise increasing numbers of indigenous African people off the land and into wage labour for the white colonists, left little appetite for "useless" prison labour solely punitive in nature. Labour was simply too valuable a commodity to waste on purely punitive penal labour. ${ }^{78}$

76 Idem par 29. It was not only the overcrowding of the country gaols that the Commission believed would be relieved by the establishment of "movable" prisons. Later in its report, the Commission indicated that overcrowding in the Central Gaols would also be relieved "if the scheme of establishing 'Movable Prisons' were adopted, the Central Gaols could also, if necessary, be relieved of their short-sentenced blacks by contributing their quota to the nearest Camp". See idem par 32.

77 One of the recommendations of the Commission was that: "Power be given to Magistrates to order a Native or Indian to be sent direct to a Labour Camp, in preference to committing him to a District Prison.” See Report of Prison Reform Commission, GN 344 Natal GG of 5 Jun 1906 par 74.25.

78 A good example of the Commission's attitude towards the value of prison labour is to be found in its criticism of the stone-breaking work that took place in the Pietermaritzburg Gaol just after the turn of the century: "At Maritzburg the principal work carried on within the gaol precincts is stonebreaking within wired partitions, presenting a distressing spectacle of caged humanity and misapplied energy, crude and archaic methods, and a disregard of the economic value of even prison labour." See idem par 31. 


\section{The implementation of the Commission's recommendations}

The recommendation of the Commission for the establishment of a completely separate prison for Europeans was never implemented during the colonial period. Despite the assurance of the Minister of Justice on 25 July 1906 that $£ 5000$ had been placed on the estimates "for the purpose of commencing the erection of an industrial gaol for Europeans", such an institution had not been built by the time the colonial period came to an end with the establishment of the Union of South Africa in 1910. An important reason for this failure was the heavy financial costs that would have been involved. ${ }^{79}$

More importantly for the purposes of this contribution, certain of the recommendations of the Commission relating to native offenders - involving much less financial cost - were implemented. These included the establishment of a number of movable prisons that "were set up in various parts of the Colony"; the creation of "a separate class ... for half casts"; and the sending of "short sentence prisoners of good conduct ... on to road parties instead of being made to serve their sentence in Gaol". 80

The establishment of the movable prisons was a particularly important development. It must be noted that, in the same year that the Prison Reform Commission delivered its report, the colony was shaken to its core by the Bambatha Rebellion. This made the establishment of the movable prisons particularly urgent in order to relieve massive overcrowding in the gaols, which resulted from a huge influx of "rebel" prisoners following the Rebellion. The use of "movable prisons" to deal with "rebel" prisoners is evidenced by the following extract from a report of the assistant Commissioner of Police:

Four Movable Prisons have been established in which rebel Native Prisoners are confined. 50 Convicts in each prison. Three of these Prisons are on the main roads of the Colony and the convicts are employed road making. The fourth Movable Prison is in the Government Experimental Farm at Cedara ... Prisoners have been doing good work and shew no inclination to escape. No prisoner with a sentence exceeding two years is sent to a Movable Prison. ${ }^{81}$

79 Legislative Assembly Debates (1906) vol 40 at 753: Minister of Justice 25 Jul 1906. In Jan 1907, the Colonial Secretary in Cape Town asked the Natal government to what extent the Commission's recommendations had been adopted. The Minister of Justice replied that "with a few exceptions the recommendations of the Commission involve legislation and up to the present nothing has been decided in respect thereof." See NAB CSO 1827/1124: Minister of Justice to Colonial Secretary 22 Feb 1907. Then, in Aug 1907, when the government was asked in parliament if any of the Commission's recommendations had been adopted, it replied as follows: "The recommendations mostly necessitate fresh legislation. Other recommendations involve very heavy expenditure in the way of new Prisons for Industrial purposes, or Reformatories." See NAB PMO 67/978: Reply to question by Mr Jameson in the Legislative Assembly on 21 Augt 1907 - Tabled in the Legislative Assembly on 29 Aug 1907.

80 NAB PMO 67/978: Reply to question by Mr Jameson in the Legislative Assembly on 21 Aug 1907 - Tabled in the Legislative Assembly on 29 Aug 1907.

81 NAB CSO 1827/1124: Report of Assistant Commissioner of Police 13 Feb 1907 par 14. 
Although not strictly speaking a movable prison, the Convict Station at the Point which was established at this time, was precisely the same type of institution as the movable prisons. The penal ideology that determined the establishment and use of the movable prisons was equally applicable to the establishment and use of the Convict Station at the Point. As in the case of the movable prisons, the Point Convict Station was meant solely for native prisoners, and was used to accommodate large numbers of native rebels. It is to the link between the Bambatha Rebellion and the establishment of the Convict Station for native prisoners at the Point that we now turn.

\section{The 1906 Bambatha Rebellion as catalyst for the construction of the Point Convict Station}

The origins of the Bambatha Rebellion were deeply rooted in the racist and oppressive structures that had been put in place in the colony of Natal by the turn of the century. In 1906, the Natal government pushed matters to a breaking point by imposing a poll tax on all unmarried males. Such a tax was imposed regardless of economic status. In January of the same year, the authorities began to collect the tax and met with resistance in certain areas. There is no doubt that Africans were infuriated by the tax, by the way it was announced, and by the manner in which the collection was implemented. ${ }^{82}$ The government struggled to contain and suppress the rebellion and ultimately did so only with assistance from the Cape colony and the Transvaal. This had a bearing on the decision of the Natal settlers to join the Union in $1909 .{ }^{83}$

Tension was created in the colony by widespread social and economic change, and it was only a matter of time before there was an outbreak of violence between black and white in the colony. This indeed happened on 8 February 1906, on a farm named Trewigie, near Richmond ${ }^{84}$ Following a confrontation in which a group of policemen made some arrests, an altercation resulted in the deaths of two policemen. Martial law was declared the next day by the governor, Sir Henry McCallum. ${ }^{85}$ Twenty-four men were subsequently tried before a military court in Richmond between 12 and 19 March, twelve of whom were sentenced to death. Others received long prison sentences and floggings. ${ }^{86}$

Although initially most attention was focussed on Richmond, there was also trouble in the Maphumulo district on the southern side of the Thukela river valley. The local magistrate had begun to collect the poll tax in January 1906 and had met with resistance. ${ }^{87}$ By March, the military mistakenly believed it had saved Natal from

82 Guy 2006: 21.

83 Thompson 2003: 533.

84 Guy 2006: 24.

85 Idem at 37.

86 Idem at 39

87 Idem at 53 . 
an uprising, but the rebellion had only just begun. A police patrol was subsequently attacked in the Mpanza valley and four policemen were killed. The attackers were led by a chief known as Bambatha kaMancinza Zondi. ${ }^{88}$

After the attack, Bambatha moved to the protection of the forests of the Nkandla district. ${ }^{89}$ Over 4000 colonial troops were mobilised and around half of these were dispatched to the Nkandla region. ${ }^{90}$ By the end of May, the conflict had reached a stalemate. ${ }^{91}$ On 13 June, however, troops investigated a report that the body of Bambatha was lying among the dead after a decisive massacre in the Mome Gorge. They cut off his head and took it to the military camp where it was identified by Zulu men who had known him. It was returned to the Mome Gorge the next day and buried with the body. However, there were subsequent reports that they had been deliberately misidentified to mislead the troops, allowing Bambatha to go into hiding. In the following months and years, there were many reports that the chief was still alive. ${ }^{92}$

The rebellion continued in Maphumulo, towards Stanger, and finally ended in July. ${ }^{93}$ The death of Bambatha was officially verified on 16 June 1906. As mentioned above, evidence of his death was presumptive, but it was now conclusive. Of the four ringleaders, three were now dead and one had surrendered to the colonial authorities. ${ }^{94}$ Martial law was finally lifted on 2 September. The rebellion had cost the government $£ 650$ 000, a sum which increased to $£ 778360$ by June 1907 . White losses numbered twenty-four, with thirty-seven soldiers wounded. Losses by the Zulus were far higher: between 3000 and 4000 were killed during the rebellion..$^{95}$

Most of the men accused of rebellion were tried by magistrates under martial law. They were convicted in batches and sentenced to two or three years' hard labour, often with flogging, and sent off to labour on government projects. An official estimate is that 4700 of the "rank and file" received sentences lasting approximately two years' hard labour and flogging. However, late in 1906, an official estimated that 7000 were imprisoned. ${ }^{96}$ Of the 7000 in gaol, a large number were hired out by the government to the Public Works Department, the Natal Harbour and Railway works, and to municipalities and collieries. ${ }^{97}$

$88 \quad$ Idem at 55.

89 Idem at 88.

90 Idem at 102.

91 Idem at 118

92 Idem at 128.

93 Idem at 140.

9416 Jun 1906 Natal Mercury.

95 Marks 1970: 237-238.

96 Guy 2006: 170.

97 Marks 1970: 237-238. 
The influx of rebel prisoners captured during and after the rebellion into the prisons of the colony clearly created a major problem in terms of overcrowding. In order to help address this problem, a sitting of the Natal Legislative Assembly on 2 July 1906 discussed, inter alia, a Bill designed to facilitate the hiring out of convicts. ${ }^{98}$ The Bill that sought to amend the Gaol Law of 1887 was put before the legislature on an urgent basis. According to the Natal Advertiser, the Minister of Justice "explained that it was a matter of great urgency, because at the present time the Natal gaols were overflowing, and there were surrendered prisoners and others in large numbers now being dealt with, and the intention of the Government was to ask Parliament to consider this Bill for the purpose of enabling the Government to hire out certain convicts so that they might be useful". ${ }^{99}$ It would seem that convicts hired out in terms of the proposed Bill would be treated more as indentured labourers than as prisoners. The Minister of Defence explained to parliament that:

The Bill would empower the Government to enter into a contract with any municipality, Town Council or other public body or individual for the employment of prisoners who have been sentenced to terms of imprisonment exceeding three months, and it was further provided that the place where the employment is to take place shall constitute a place of confinement or prison within the meaning of the Gaol Law. ${ }^{100}$

The Gaol Law of 1887 was duly amended in 1906 and a set of regulations were approved by the governor in council for the employment of convicts in terms of the amendment. ${ }^{101}$ In terms of regulation 7 :

The Government will put to the credit of, or pay to, each convict who works satisfactorily the sum of 3s. per mensem, and in the case of a convict working underground in a mine the sum of 6s. per mensem, with an additional sixpence in respect of each Sunday on which the convict has worked. The Chief Commissioner of Police may stop any such payment to a convict in case of misbehaviour or breach of discipline. ${ }^{102}$

The above regulation seems to indicate that convicts who were hired out in terms of the above scheme were not considered to be criminals in the normal sense of the word, but rather as political offenders who needed to be taught that their proper role in colonial society was to perform hard labour in service of the white colonists in return for menial wages.

Following the rebellion, hundreds of rebels were also imprisoned at the Point. Initially, these men were temporarily held in municipal labourers' barracks at Bell Street, near the Point, which was declared a prison by government proclamation. ${ }^{103}$

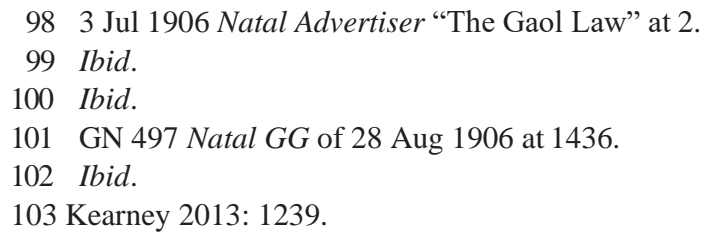


Essentially, the rebels were divided into four large gangs - the largest of which was stationed at the Point - and used as labour on various public works programmes. A second gang was situated at the concentration camp at Jacobs, south of Durban, and the remaining two gangs were "housed in wood and iron huts and compounds surrounded by barbed wire" elsewhere in the colony. ${ }^{104}$

By August 1906, there were 370 rebels alongside 240 regular convicts and 896 contract workers on the Point and the Bluff. During 1906, an average of 1477 worked at the Point, which resulted in a significant reduction in the number of contract workers. As the rebels were classed as political prisoners, no wages were paid by the Natal Harbour Department. From 1907, their numbers began to decrease although there were still 907 by the end of that year. In 1908, many of the remaining rebels were moved to Congella to work on the new wharfs being constructed at that site. ${ }^{105}$

The proposals of early harbour engineers Milne and Innes were remembered and a decision was made to house the new prisoners at the Point. In August 1906, $£ 30000$ was made available for the construction of the new Point Convict Station, other facilities and portable gaols in the colony. ${ }^{106} \mathrm{~A}$ year later, the Weekly Mercury reported that the foundation was being prepared for a new gaol for rebels at the Point, which was to be constructed from wood and iron and which would accommodate 1 500 prisoners. ${ }^{107}$

The construction of the prisons was described in the Weekly Mercury as a Public Works Department "rush job". ${ }^{108}$ While gangs of rebel prisoners engaged in levelling reclaimed land at the end of the Point, a large number of artisans worked day and night in the erection of a series of wood and iron barracks. The site, near Durban's south beaches, was considered to be a healthy one for the prisoners. One of the main reasons why the prison was built was because the colonial government had received instructions to clear the compound situated at Jacob's as it was needed by the Transvaal Chamber of Mines to temporarily house Chinese labourers. The Point Prison consisted of four blocks to house the prisoners, with additional blocks for stores, offices, warders' quarters and kitchens. A large amount of "old harbour material" had been used in the construction to save costs. Just over 100 white artisans and several hundred rebel prisoners worked on the project. ${ }^{109}$

The Natal Harbour Department workshops were well-equipped and the department assisted in the construction of the new prison. ${ }^{110}$ In 1907, there were reports that second-hand pine logs were sawed in preparation for the building of the

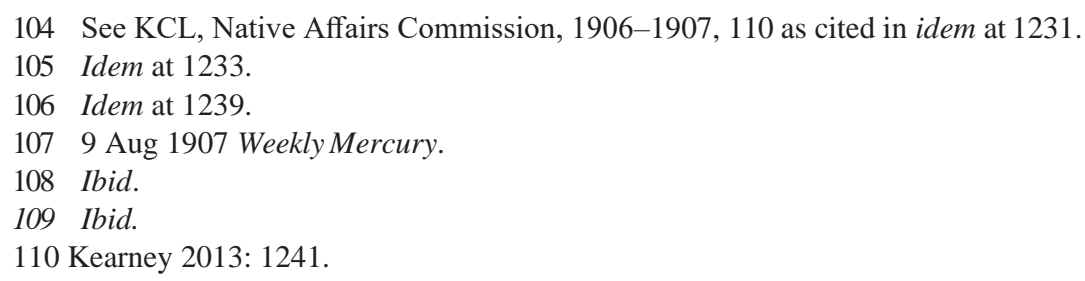


prison and that the department provided "large amounts of timber, rubble, sand and binding for the prison". ${ }^{111}$

The total cost of the wood-and-iron building as well as its running costs were paid out of the Native Rebellion Expenditure account. ${ }^{112}$ With time, the wood-andiron structure required additional ventilation, and to improve thermal conditions, the Public Works Department lined the cells with an additional layer of corrugated iron sheeting in $1908 .{ }^{113}$ The new Convict Station was officially proclaimed as a central gaol in the Government Gazette on 24 August 1907. ${ }^{114}$

During the first two years of its operation, the prison held a total of 2316 prisoners. The facility was designed to house 1150 prisoners at a time in twentyone cells. The daily average number of prisoners was 1381 and the greatest number held on any one day was 1691 . Clearly, there was a problem with overcrowding from the earliest years of its operation. During the period when the prison housed rebels, 165 men died, many from old age and sickness, and two escaped. In 1906, the Department of Health noted a high incidence of tuberculosis among rebels in general and there was a special section in the prison for tuberculosis patients. The rebels held at the Point mainly worked on removing sand hills, on building roads and on assisting with the construction of stone retaining walls. In addition to the Point prison, over 1000 rebels were incarcerated in the old Anglo-Boer War concentration camp in Jacobs and on a prison farm at the south coast. ${ }^{115}$ On 1 January 1908, 1503 prisoners were housed in the gaol. ${ }^{116} \mathrm{~A}$ year later, by contrast, this number had been reduced to 524 (of which 100 were Indian and 424 African) and the average daily number of prisoners housed in the facility was 478. By 1909, there were 106 separate cells, an increase of eighty-five, with a total floor space of 22180 square feet. ${ }^{117}$

Possibly because of the political implications there are scarcely any official records of the Point Convict Station. A few references to the prison can be found in the Natal Police journal, Nongqai. It was reported in 1907 that Inspector Deane, who had been appointed governor of the new prison, was "converting the hitherto barren sandbanks into a really smart and clean gaol". ${ }^{118}$ As a large number of prisoners had not been convicted of any crime, the authorities decided to declare the new prison a branch court. ${ }^{119}$ It is likely that the environmental conditions were worse than those prevailing in the Durban gaol. Though the lightweight wood-and-iron structure was

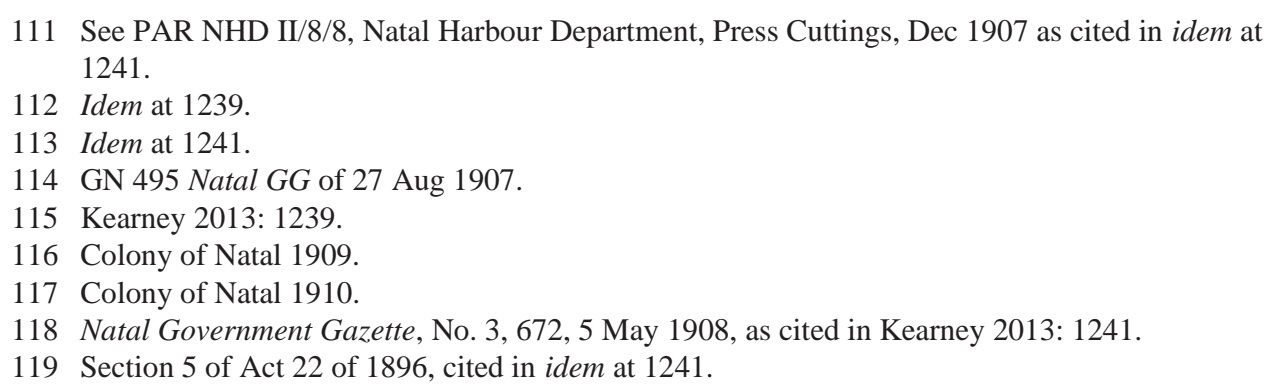


appropriate for the humid coastal climate, it only worked effectively with sufficient

ventilation, which was unlikely in a prison of this kind. ${ }^{120}$ Hence the decision to improve thermal conditions being carried out in 1908. Some rebels were still being held at the Point as late as 1908; this was confirmed in a sardonic statement by one of the warders stating that "[o]ur health resort is well patronised by a fairly representative gathering of the inhabitants of the districts in Natal and Zululand". ${ }^{121}$

What is clear from the above is that, as the colonial period drew to a close and the colony of Natal began its transition to becoming part of the Union of South Africa in 1910, the Point Convict Establishment had well and truly begun its life as one of South Africa's major prisons, with a unique set of penal ideologies already encoded within its historical DNA.

\section{Conclusion}

This contribution set out to examine the early history of a building situated in Durban's upmarket Point Waterfront Development Area. Before the overall gentrification of this area, the building used to operate as Durban's notorious Point Prison. As explained, the overall genesis of the Point Prison can be traced back to colonial times at the turn of the twentieth century, when this institution was known as the Point Convict Establishment or Station. We claim in the introduction that this building is of interest for more than the mere fact that it used to be a prison, since tied up in its history are many themes that are unique to the peculiar penal history of southern Africa in general, and of KwaZulu-Natal in particular.

We show that the Point Convict Establishment was conceived at a time of increasing racial tension within the colony of Natal. Just after the turn of the twentieth century, there was increasing pressure from the white colonists for the establishment of a completely separate penal system for European prisoners. This general idea received overwhelming support from the white colonial authorities and became a central pillar of the recommendations put forward by the 1905-1906 Prison Reform Commission. On the other side of the coin, the white colonial authorities also believed that the manner in which Native and non-European prisoners were dealt with needed to be reformed. We illustrate above that the prisons of colonial Natal were used, to a significant extent, as instruments for exercising white colonial social control over the indigenous population. It was felt by many within the white colonial establishment that a large proportion of the non-European prisoners in the colony's gaols - particularly those who had committed petty offences against social-control legislation - should be removed and accommodated in such a way that they could most effectively be put to work on public works within the colony,

120 Ibid.

121 See Nongqai, II (12), 1909, 392 as cited in ibid. 
such as the roads and the main harbour at Durban. The Point ConvictEstablishment was originally conceived as a cost-effective way of accommodating non-European convict labourers, who would supply cheap labour to the harbour works. Further, as pointed out towards the end of this contribution, the immediate catalyst for the construction of the Point Convict Establishment was the need to accommodate large numbers of rebel prisoners captured during the Bambatha Rebellion of 1906. This dovetails with our observation that, to a significant extent, the penal system of colonial Natal was not only designed to reduce criminality in the usual sense of the term, but to act as an instrument of white colonial social control over the rebellious indigenous population.

This contribution explains in detail both the practical (economic) and ideological importance of penal labour, particularly when it came to the punishment of nonEuropean prisoners. On the ideological side of things, we point out that, for the white colonists, convict labour performed by black prisoners was considered crucially important, since a central pillar upholding and advancing the colonial project was the successful coercion of the indigenous black population into the habit of performing regular hard labour in service of their white colonial masters. The fact that the Point Convict Station was designed as accommodation for non-European convict labourers is, therefore, significant. Of further significance is the fact that the establishment of the Point Convict Station was part of a wider plan to completely separate the punishment of European from non-European prisoners - a process we term "racially differentiated punishment".

It is worth reiterating the general point that the development - early in the twentieth century - of a penal ideology based explicitly on the separation of different racial groups, is clearly significant if for no other reason than that this took place almost half a century before the inception of the notorious apartheid system in South Africa. We conclude by affirming our contention that, if the buildings which make up today's 'Point Bastille' could talk, they would reluctantly acknowledge their place within South Africa's cruel history of racial segregation and suffering.

\section{Bibliography}

Brookes, Edgar H \& Colin de B Webb (1965) A History of Natal (Pietermaritzburg)

Bundy, Colin (1979) The Rise and Fall of the South African Peasantry (London)

Colony of Natal (1909) Statistical Year Book for the Year 1908 (Pietermaritzburg)

Colony of Natal (1910) Statistical Year Book for the Year 1909 (Pietermaritzburg)

Graves, Adrian \& Peter Richardson "Plantations in the political economy of colonial sugar production: Natal and Queensland, 1860-1914" J of Southern African Studies 6(2): 214-229

Guy, Jeff (2006) Remembering the Rebellion: The Zulu Uprising of 1906 (Durban)

Kearney, Brian (2013) Alas, Poor Little Colony: An Illustrated History of Port Natal (Durban) 


\section{PAUL SWANEPOEL AND STEPHEN PETÉ}

Kline, Benjamin (1988) Genesis of Apartheid: British African Policy in the Colony of Natal, 18451893 (Lanham, MD)

Lambert, John (1995) Betrayed Trust: Africans and the State in Colonial Natal (Pietermaritzburg)

Lambert, John \& Robert Morrell (1996) "Domination and subordination in Natal, 1890-1920" in Robert Morrell (ed) Political Economies and Identities in KwaZulu-Natal: Historical and Social Perspectives (Durban): 63-95

Marks, Shula (1970) Reluctant Rebellion: The 1906-9 Disturbances in Natal (Oxford)

Peté, Stephen A (1984) The Penal System of Colonial Natal: From British Roots to Racially Defined Punishment (LLM, University of Cape Town)

Peté, Stephen A (2006) "Falling on stony ground: Importing the penal practices of Europe into the prisons of colonial Natal (Part 1)" Fundamina 12(2): 100-112

Peté, Stephen A (2007) "Falling on stony ground: Importing the penal practices of Europe into the prisons of colonial Natal (Part 2)" Fundamina 13(2): 111-125

Richardson, Peter (1982) “The Natal sugar industry, 1849-1905” J of African History 23(4): 515-527

Thompson, Paul S (2003) "The Zulu rebellion of 1906: The collusion of Bambatha and Dinizulu" International J of African Historical Studies 36(3): 533-557

Warwick, Peter (1980) "Black people and the war" in Peter Warwick (ed) The South African War: The Anglo-Boer War 1899-1902 (Harlow, Essex): 186-209

Wassermann, Johan M (2011) "The suspects are not to be treated as prisoners or convicts - a labour camp for Africans associated with the Boer Commandoes during the Anglo-Boer War" J for Contemporary History 36(2): 25-47

Wassermann, Johan M \& Annette Wohlberg (2002) "Boer prisoners of war" in Johan M Wassermann \& Brian Kearney (eds) A Warrior's Gateway: Durban and the Anglo-Boer War 1899-1902 (Pretoria): 112-141

\section{Legislation}

Identification of Native Servants Act 49 of 1901 (Natal)

Natal Native Code of 1891 (Natal)

Masters and (Black) Servants Act 40 of 1894 (Natal) 